\title{
Perspectives of Administrative Legal Proceedings Improvement in Conditions of Digitalization
}

\author{
Sultanov K.A. ${ }^{1, *}$ Kostennikov M.V. ${ }^{2}$ Kashkina E.V. ${ }^{3}$ \\ ${ }^{1}$ Department of civil and labor law, civil procedure, Moscow University of the ministry of internal affairs of the Russian \\ Federation named after V.Ya.Kikot, Moscow, Russia \\ ${ }^{2}$ Department of police training for public order units and migration units of the police training Center for public order \\ units All-Russian Institute for Advanced Studies of the Ministry of Internal Affairs of Russia, 142007, Domodedovo, \\ Russia \\ *Corresponding author. Email: mpkr@mail.ru
}

\begin{abstract}
The article deals with the main directions of the Russian legislation improvement in the field of digitalization of administrative legal proceedings and administrative proceedings. Explicitly, the digitalization of the administrative legal proceedings in the Russian Federation requires consolidation and improvement. In connection with this, the process under consideration has, in essence, high actuality and legal importance. This subject actuality is practically assured. So far, all state authorities are interested in the digitalization of all stages of administrative legal proceedings. For the implementation of the goals set, the adoption of the priority regulatory acts is required. The regulatory acts adopted provide for the creation of conditions for eproceedings, providing for the simplification of the procedures for filing statements of claim, and appeals in e-form. The authors made an attempt to interpret specifically the modern electronic (digital) environment with regard to current laws and regulations in the Russian Federation and foreign legislation. the extraordinary proposals, aimed at improving the process of digitalization of all stages of administrative legal proceedings and administrative proceedings, were offered.
\end{abstract}

Keywords: digital environment, digital rights, digital imperative, digitalization, law offense, administrative

court proceedings

\section{INTRODUCTION}

For the time being, the comprehensive improvement of the administrative process mechanism, both in the judicial and in the administrative order, is impossible without supporting the extended user access to high tech equipment and the development of digital services at all stages of the administrative process. Being the main moder trend, digitalization penetrates into all spheres of human everyday life, considerably updates the activities of professional communities, and state institutions stand on the threshhold of considerable technology transformations. According to experts, the business and the state are interested in the algorithmization of legal processes and law making that will allow decreasing transaction costs and increasing efficiency [1]. At the same time, the law is the conservative phenomena. According to some estimates, the level of technology penetration into

jurisprudence does not exceed 30 per cent today, and the share of available online services does not exceed 4-5 per cent. Achieving the legal digitalization, according to experts' assessment, will be provided within the implementation of the National Technology Initiative, national projects "Science", "Digital Economy of the Russian Federation".

In modern scientific discussions dedicated to digitalization, without regard to the law system and law sector in which this discussion is held, the issue of the conventional law transformation under the influence of digital technologies in the digital society conditions, is raised. Simultaneously, the transition from the instrumental approach in the analysis of the use of digital technologies in law enforcement to their informative comprehension, the change in the essence of law enforcement activity and law "de-legalization", is observed [2]. Common markers of law transformation in scientific literature include the appearance of the following law categories:

1. new subjects of law (virtual personality, digital image, robots), requiring doctrinal development of possible models for admitting the legal identity in highly developed robotic machines;

2. artificial intelligence that determines the legal regime (universal counselor); 


\section{3. new digital (constitution) right.}

Today, the term "digitalization" is used both in narrow and wide sense. In a narrow sense, digitalization means the information transformation into the digital form that in most cases leads to the decrease of expenditure, appearance of new possibilities, etc. The most part of the specific information transformations into the digital form leads to such considerable positive consequences that make grounds for using the term "digitalization" in a wide sense. As the transfer of all sides of economic and social life to digital information, digitalization, that was earlier a simple metod to improve various private sides of life, now becomes the driver of global social development, providing the increase of the economy efficiency and the life quality improvement [3]. For this reason, in a wide sense, digitalization means the modern global trend of the economy and society development, based on the information transformation into the digital form and leading to the economy efficiency increase and the life quality improvement. In a wide sense, digitalization can be considered a trend of the efficient global development only in the case if the information digital transformation meets the following requirements: it covers production, business, science, social sphere and normal life of citizens; it is accompanied only by the efficient use of its results; its results are available to the transformed information users; its results are used not only by specialists but also by common citizens; digital information users have skills of using it.

For example, in the time being, information innovations (filing lawsuits and their registration in electronic form, case movement between courts in e-form, session in the video conference format, sending notifications to the judicial process participants by SMS messages or via email, etc.) are being actively implemented into the administrative activity of state authorities [5]. However, these innovations should not affect the essence of the decision-making mechanism in terms of case verdict, and it should remain the court's or the official's exclusive prerogative. We are in solidarity with the position of N.A. Petukhov and M.V. Chizhov concerning their opinion that "information and communication technologies applied in the course of justice implementation are one of the ways to increase the justice efficiency but don't prove the transfer to the new form of justice, electronic justice." The artificial intelligence use cannot and should not replace the adoption of a grounded decision by a lawyer, a specialist, according to his/her inner judgment, as it is prescribed by the justice principles [6,7]. As T.Ya. Khabrieva and N.N. Chernogor fairly emphasized [4], "all legal regulations, including procedural ones, and the methods developed by law science, never contain complete information for resolving the specific case, the situation.

\section{RESEARCH METHODOLOGY}

The methodological base of this study was compiled by general scientific methods of cognition, including the principle of objectivity, systematicity, induction, deduction, etc. Along with general scientific methods of cognition, private scientific methods, i.e. descriptive, linguistic, and comparative-legal, were used. The study topic is disclosed from the standpoint of general scientific methods (sociological, systemic, structural and functional, concrete historical, and statistical), general logical methods of theoretical analysis, and private scientific methods (comparative law, technical legal analysis, concretization, and interpretation). In connection with the foregoing, a comparative study of the state of Russian administrative process under the continuous influence of information technology seems relevant. Comparison and analysis will be carried out based ont he experience of the German system of digital administrative legal proceedings. The use of the comparative-legal method is due to the universal phenomenon of the digitalization of law.

\section{RESEARCH RESULTS}

The use of information and telecommunication technologies, already existing and functioning e-services, information systems, state and municipal service portals should be implemented with the purpose to simplify the implementation of citizens' rights. However, citizen don't always have a possibility to use such rights in the full volume [8]. For example, the Constitution of the Russian Federation considers the right to appeal as one of the most important civil rights. The special category is represented by appeals on judgments on the cases of administrative offences.

However, the current edition of RF AOC does not establish (in distinction, for example, from RF CPC) the procedure of appealing to the competent authorities. It should be understood that the current legislation always has to meet the social and economic realia; otherwise, the law will fail to play the role of the efficient public relations regulator. Recently, a bill has been entered to the National Duma of the Russian Federation, according to which, it will be possible to file appeals in cases for administrative offenses in electronic form (Draft Federal Law No. 608427-7 "Concerning the Introduction of an Amendment to Article 30.2 of the Russian Federation Administrative Offence Code (in the part of specifying the complaints procedure for judgment on the case of the administrative offense)). In our opinion, the approach offered will allow unifying the procedure of submitting appeals to judgments on the cases of administrative offenses, that will simplify the procedure of submitting such appeals for citizens, simplify the operation of law enforcement authorities and provide the possibility of meeting the citizens' rights for appealing.

The current Russian Federation Administrative Offence Code No. 195-FZ of 12/30/2001 (hereinafter - RF AOC) 
partially provides for the automation of the administrative proceedings in case if the administrative offense was committed in the field of traffic safety or in the field of the territory improvement with the vehicle use. With the purpose of detecting and registering such administrative offenses, the legislator provided for the use of dedicated automatic technical means with photo and film shooting and video recording functions. Along with the introduction of the possibility of automatic registration of administrative offenses, the legislator established the line of features connected with it.

The first feature is the valid presumption of innocence (note to Art.1.5, Art. 2.6.1 RF AOC), in accordance with which, in case of the automatic registration of administrative offense, all owners of transport vehicles are brought to administrative responsibility. In scientific literature, this legislative method is assessed as consolidation of the "presumption of innocence." According to the legal position of the Russian Constitution Court, the specific prosecution order means in this case that the authorized agencies are not obliged to prove the guilt of owners of transport vehicles at making judgments on the cases of administrative offenses in relation to them. The second feature is the simplification of the administrative proceedings (Art. 28.6 RF AOC), the administrative penalty is assigned without the drawing up a protocol of the administrative offense.

The third feature is that the copy of the judgment on the case of administrative offense can be sent both in the written form (hard copy), and in the form of an edocument signed with the authorized official's enhanced encrypted and certified digital signature, use of the Public Services Portal of the Russian Federation.

The fourth feature is accounting the automatic method of registering the administrative offense when the legislator determines the amount of administrative penalty.

\section{DISCUSSING THE RESULTS}

Analyzing the above, it should be noted that in the whole, the administrative proceedings, contrary to the other administrative process types, still has not received the proper "through" digitalization of all production stages in terms of e-communication and e-document circulation. Let us consider two examples. The first example is about sending e-mail notifications of the administrative offense. The legislator admits such a possibility but does not provide for the requirements to this form of communication between the subject carrying out the administration proceedings, and the subject of these proceedings, which gives rises to considerable practical complications in terms of providing the due notification and creates a basis for procedural rights abuse. The second case was considered earlier and is connected with the absence of digitalization at the stage of reconsideration of the judgment in the case of an administrative offense.

Prior to adoption and coming into force of APC RF $(09 / 15 / 2015)$ proceedings in cases arising from public law were carried out by courts within civil and arbitration court proceedings. This gave rise to the line of discussions about the ratio of the civil and administrative form of action, that did not cease but, on the contrary, intensified after this code was adopted [9]. Independently on the attitude to arguments of supporters and opponents of APC RF, it can be admitted that legal measures of civil form of action, taht were polished during decades, are fixed in APC RF regulations, including modern e-forms of documentation and electronic means of interaction between the court proceedings participators. According to the report "Global Information Technologies", the Russian Federation holds the 41st place in terms of readiness to the digital economy (Network Readiness Index, NRI) and is in the middle of the second group of countries (overtaking) in terms of Digital Economy and Society Index (I-DESI) [10].

The increasing number of the citizens of the Russian Federation admits the need for digital competencies, however, the indicators of the use of personal computers and the Internet information and telecommunication network in the Russian Federation are still lower compared to Europe [11]. There is a gap in digital skills in various population groups (in 2019 , the share of population with digital skills was only 27 per cent according to the results of PIAAC international study) [12]. The use of digital technologies in the education system is extended but the volumes of $\mathrm{HR}$ specialized preparation and the correspondence of education programs to the needs of the digital economy are not sufficient [13].

\section{CONCLUSIONS}

The existing regulatory environment does not meet the tasks of making the regulation of public relations, their readiness to response to the ever-changing technology context, more flexible. Despite the systemic steps for business climate improvement, the law still has many gaps, administrative obstacles preventing the development of business based on the use of information technologies, work with data [14]. On the whole. a mechanism of managing changes in the sphere of digital economy regulation is required, which will provide timely adaptation of legal regulation to digital development tasks. Russian post-Soviet administrative law science in the conditions of adaptation to the new system of values fixed in the Russian Constitution of 1993, and the information society civilization development acceleration, do not always have time to transform classic law institutions (such as administrative procedures), and, moreover, to carry out thorough development of new law categories (an administrative agreement, automated administrative act, a delegation of public functions, etc.). This applies to the full extent to digital technologies in the public management area that are being implemented faster than law and science adapt to them.

The uneven nature of digital technologies advancement in various production types is conditioned by the absence of the uniform law on administrative procedures, which, in its turn, reflects the state of the administrative science that did not offer the legislator any adequate concept oof public 
Rossii i Germanii. Vestnik Sankt-Peterburgskogo universiteta. Pravo. 2019. T. 10. No. 4. S. 756-780.

positive management to realize functions and competence of public authority subjects through the administrative procedures, and negative, burdening management, related to the administrative enforcement [15]. In the course of the administrative reform, the unified institution of administrative procedures was actually replaced by the procedure for public services provision, which made the coordination of these procedures with the other procedures that mediate the power entities' activities, impossible. As the result, the institution of administrative procedures was not digitalized; it happened only to its part,t he procedure of public service provision.

Therefore, the Russian administrateive law faces the task of digitalization of the specifically unified administartive law. So far, digitalization of separate procedures and production types takes place, which inevitably affects different approaches to this process. When compared to German administrative law, it is seen that the single codified act on administrative procedures allows carrying out a more uniform transfer to the digital administrative procedure in all public management areas.

A new instrument of the implementation of public management functions in Russian administrative law, that originated from the artificial intelligence implementation into the public administration area, is an automated administrative act that allows making the arbitrary decision by computer, without human involvement. The "semi-automatic" administrative act is actively used in Russian administrative law in administrative proceedings. Inevitably, the social essence of public administration raises the issue of limits of total digitalization of the managerial process applied to those types of industries that affect human rights, freedoms, and legal interests.

In the sphere of administrative legal proceedings in Russian law, digitalization is smoother compared to the digitalization of administrative procedures. This is due to the fact that by the time the CAS of the Russian Federation was adopted, the experience of digitalization of the arbitration process had already been accumulated, productively used in the development and implementation of digital technologies in administrative court proceedings. Due to the existing codification of administrative legal proceedings, the rather detailed regulation of electronic forms and the smart introduction of digital technologies, the Russian administrative court proceedings advance the practical digitalization of the court and administrative proceedings in some issues.

\section{REFERENCES}

[1] D.M. Nazarov, B.K. Rodin, Legaltech kak osnovnoy trend tsifrovizatsii yuridicheskoy deyatel'nosti. V sbornike: BI-tekhnologii i korporativnyye informatsionnyye sistemy v optimizatsii biznes-protsessov tsifrovoy ekonomiki. 2019. S. 69-73.

[2] U. Kramer, L.A. Mitskevich, A.F. Vasil'yeva, Elektronnyye formy $\mathrm{V}$ administrativnom protsesse
[3] K.V. Pavlov, N.R. Asadullina, Formy i osobennosti tsifrovizatsii ekonomiki na postsovetskom prostranstve. V sbornike: Problemy bezopasnosti. 2020. S. 37-38.

[4] Ye.Ye. Tonkov, L.A. Pozharova, Pravovoye regulirovaniye $\mathrm{v}$ usloviyakh tsifrovizatsii obshchestva: problemy i perspektivy. Nauchnyye vedomosti Belgorodskogo gosudarstvennogo universiteta. Seriya: Filosofiya. Sotsiologiya. Pravo. 2019. T. 44. No. 3. S. 490-497.

[5] Ian Hargreaves. Digital Opportunity: A Review of Intellectual Property and Growth. London: HM Government, 2011. C. 53: http://www.ipo.gov.uk/ipreview-finalreport.pdf

[6] Digital Economy Act, 2017. Available at: http://www.legislation.gov.uk/ukpga/2017/30/pdfs/ukp ga_20170030_en.pdf

[7] Mastering the Digital Imperative. Digital BCG, 2019. Available at: https://www.bcg.com/expertise/digital-bcg/default.aspx

[8] NHS cyberattack: Seven trusts still turning away patients. Available at https://news.sky.com/story/europol-warns-of-furthercyberattacks-on-monday-morning-10876985

[9] A.B. Zelentsov, O.A. Yastrebov, Sudebnoye administrativnoye pravo: Uchebnik dlya studentov vuzov, obuchayushchikhsya po spetsial'nosti "Yurisprudentsiya". M .: Statut, 2017.

[10] A.I. Pominova, Tsifrovyye tekhnologii napravleniye sovershenstvovaniya gosudarstvennogo upravleniya (na primere g. Moskvy). Ekonomika i predprinimatel'stvo. 2019. No. 2 (103). S. 425-427.

[11] S.G. Tyaglov, I.V. Chubukova, Razvitiye tsifrovoy ekonomiki na predpriyatii i $\mathrm{v}$ organizatsii sotsial'noy sfery. Mezhdunarodnyy zhurnal ekonomiki i obrazovaniya. 2019. T. 5. No. 1. S. 5-28.

[12] BRICS Media Initiative. Available at: https://bricsmagazine.com

[13] Finance \& Development, The Long and Short of The Digital Revolution. 2018. Vol. 55, No. 2. P. 6.

[14] International Federation of Robotics. Available at: https://ifr.org

[15] Committee of Sponsoring Organizations of the Treadway Commission, 2018. Available at: https://www.coso.org/Documents/COSO-CROWECOSO-InternalControl-Integrated-Framework.pdf 